\title{
GLOBALISASI PERBANKAN SYARIAH: TINJAUAN TEORITIS DAN PRAKTIS DALAM MENGHADAPI MASYARAKAT EKONOMI ASEAN 2015
}

\author{
Hayat \\ Universitas Islam Malang Jl. MT. Haryono 193 Malang, 65144 \\ E-mail: hayat.150318@gmail.com
}

\begin{abstract}
Abstrak. Masyarakat modern telah mengalami banyak perubahan dalam tata pikir terhadap perbankan sehingga persfektif tekstualitas hukum terhadap perbankan menjadi negatif. Perbankan syariah mengalami berbagai dinamika; tantangan terhadap persaingan dalam meningkatkan kualitas pelayanan terus dilakukan dengan berbagai kemudahan, kemanfaatan, kebergunaan, kebaikan, dan menciptakan sebuah hukum yang tidak melanggar hukum Islam, menjadi sebuah keniscayaan. Masyarakat modern seyogyanya tidak lagi memandang apa yang ditonjolkan oleh perbankan, namun lebih kepada aspek pelayanan yang baik, manfaat yang dirasakan, keamanan terhadap nilai jasa, dan berbagai kemudahan yang diterimanya. Agar dapat diterima secara menyeluruh oleh masyarakat modern. perbankan syariah tidak lagi melihat latar belakang nasabahnya, namun harus mengembangkan aplikasinya terhadap apa yang dibutuhkan oleh nasabah dalam pelayanannya.
\end{abstract}

Abstract. The thought modern society towards banking system has undergone various changes so that their textual perspective to the banking law becomes negative. The Syariah banking has undergone a variety of dynamics. Challenge to the competition to improve the quality of service continues to conduct by giving various ease, usefulness, usability, kindness, and to make a law that does not violate any of the laws of Islam, became a necessity. Modern society should no longer view the symbol highlighted by the banks, but rather the aspect of their service, the benefits gained, the security of service value, and the ease obtained. In order to be accepted by the whole modern society. the Islamic banking should no longer consider the background of its customer-to be, and must develop the service required by customers, instead.

Kata Kunci: transformasi, perbankan Islam, Ekonomi Islami 


\section{PENDAHULUAN}

Pertumbuhan ekonomi Indonesia terus mengalami perkembangan dan dinamikanya. Konsep dasar dalam perbankan adalah memberikan keamanan, kenyamanan, dan kemudahan bagi masyarakat dalam menjaga dan memelihara serta memanajemen keuangannya. Secara prinsip perbankan mempunyai peran penting dalam memanajemen keuangan masyarakat, dalam rangka menciptakan kondisi masyarakat yang sejahtera dan aman dalam bidang keuangannya.

Banyak program dan produk yang ditawarkan dalam perbankan, seperti pemberian modal bagi masyarakat yang membutuhkan modal usaha, pinjaman untuk pembelian kebutuhan masyarakat seperti rumah, kendaraan, maupun kebutuhan yang sesuai dengan standar yang ditentukan, begitu juga dengan berbagai produk untuk kesejahteraan masyarakat, misalnya produk simpanan yang memberikan kemudahan dengan aspek keuntungan bagi masyarakat, simpanan bagi kebutuhan anak-anak dalam kebutuhan pendidikan, kesehatan, maupun jiwa sebagai bentuk asuransi bank terhadap masyarakat.

Secara praktis, perbankan mempunyai peran penting atas kebutuhan masyarakat. Aplikasi yang dibangun di dalam perbankan seyogyanya untuk kepentingan dan kebutuhan keuangan masyarakat yang disimpankan oleh bank dan dapat diambil kembali jika dibutuhkan. Perkembangan perbankan menjadi sebuah kebutuhan bagi masyarakat modern saat ini, yaitu dengan prinsip kemudahan dan praktis bagi setiap kebutuhan masyarakat. Masyarakat modern membutuhkan sebuah pekerjaan yang instan, yaitu tidak mau "repot" dalam kebutuhannya, maupun menyimpan uangnya.

Perkembangan perbankan terus mengalami geliat yang semakin kuat dan sehat. Pertumbuhan ekonomi masyarakatpun semakin meningkat, jika dinilai dari aspek pengeluaran masyarakat yang semakin tinggi. Hal ini dibuktikan oleh semakin 
mahalnya kebutuhan masyarakat dalam pasar local maupun nasional. Walaupun dalam perkembangannya, peningkatan ekonomi masyarakat belum diimbangi oleh kemiskinan yang sangat jauh. Namun dalam kondisi yang nyata, masyarakat sudah mampu mengimbangi harga-harga kebutuhan dengan konsepsi yang dimilikinya.

Meningkatnya pertumbuhan perbankan merupakan keniscayaan atas dasar kebutuhan masyarakat atas hartanya. Hal itu terlihat dari bermunculannya perbankan syariah dalam skala yang lebih besar. Konsep perbankan syariah didasarkan atas ekonomi secara Islam yang berlandaskan kepada ketentuan alQuran dan al-Hadist. Islam sangat berhati-hati terhadap transaksi dalam bidang ekonomi, karena didalamnya mengandung unsurunsur yang mengarah kepada kebathilan.

Sejarah perkembangan perbankan syariah dimulai pada tahun 1983 yang dikeluarkan atas adanya Paket Desember 1983 (Pakdes 83) yang mengatur tentang regulasi perbankan. Salah satunya adalah pengaturan tentang pemberian bunga 0\% (zero interest). Pada perkembangannya, muncul Pakto 88 (Paket Oktober 1988) yang memberikan deregulasi terhadap kemudahan untuk membangun perbankan'. Oleh karena itu, pada tahun 1991 berdirilah Bank Muamalat Indonesia (BMI) sebagai satu-satunya bank yang menggunakan prinsip bagi hasil yang didasarkan pada Undang-Undang Nomor 7 tahun 1992 tentang perbankan dan Peraturan Pemerintah Nomor 72 tahun 1992 tentang bank yang berdasarkan atas bagi hasil ${ }^{2}$.

BMI sebagai bank yang menganut sistem bunga $0 \%$ merupakan satu-satunya bank yang mengatur perekonomian secara Islam, yang didasarkan kepada hukum-hukum ekonomi

${ }^{1}$ Abdul Ghofur Anshori, "Sejarah Perkembangan Hukum Perbankan Syari'ah di Indonesia dan Implikasinya bagi Praktek Perbankan Syari'ah", dalam La_Riba, Jurnal Ekonomi Islam, Volume II, Nomor 2, (Desember 2008), h. 161.

${ }^{2}$ Ibid. 
Islam. Sebagai bank syariah, ditengah pesatnya perkembangan bank konvensional, mempunyai tantangan tersendiri dalam dinamika ekonomi secara nasional, padahal secara geografis, masyarakat Indonesia mayoritas beragama Islam, yang notabene mempunyai harapan besar atas munculnya bank syariah yang berdasarkan kepada al-Quran dan al-hadist.

Al-Quran dan al-Hadits secara tegas sudah mengatur tentang ekonomi Islam yang menekankan pada aspek ribawi, gharar, dan hal-hal yang mengarah kepada sebuah kebatilan dan kemudharatan ${ }^{3}$. Praktek ekonomi Islam harus dilakukan secara benar dan baik sesuai dengan ketentuan dasar al-Quran dan alHadist sebagai sumber dalam implementasinya. Sehingga perbankan syariah tidak hanya berlabelkan Islam, namun lebih kepada aplikasi realitas dalam transaksinya.

World Islamic Banking Competitiveness Report 2011-2012 dalam $18^{\text {th }}$ Annual The World Islamic Bank Conference 2011 dikatakan bahwa keberadaan ekonomi global dan pasar keuangan mengalami titik balik yang sangat signifikan. Tahun 2010 ekonomi di Asia, Afrika, Timur Tengah, Amerika Latin dan Eropa Timur menyumbangkan 70\% terhadap pertumbuhan ekonomi secara global. Lebih lanjut disampaikan bahwa diperkirakan pertumbuhan perbankan syariah secara global mampu menembus \$1.1 triliun pada tahun 2012 dengan asumsi pada tahun 2010 \$ 826 miliar. Sementara itu, menurut pendapat UK Islamic Finance Secretariat dalam Islamic Finance 2012 Report dikatakan, bahwa pada tahun 2010 asset global keuangan syariah mencapai \$ 1.130 yang diperkirakan akan menembus angka \$ 1.289 triliun pada tahun 2011. Perkembangan perbankan syariah di Indonesia mengalami perkembangan yang cukup fantastis. Tahun 2011 sesuai dengan penilaian dari Global Islamic Finance Report (GIFR)

${ }^{3}$ Taufiqul Hulan, “Jaminan Dalam Transaksi Akad Muḍārabah Pada Perbankan Syari'ah", dalam Jurnal Mimbar Hukum, Volume 22, Nomor 3, (Oktober 2010), h. 522. 
dalam rangka Milad ke-8 IAEI, 13 April 2012, Halim Alamsyah mengungkapkan bahwa Indonesia mempunyai potensi yang kondusif dalam pengembanan industry keuangan syariah setelah Iran, Malaysia dan Saudi Arabia ${ }^{4}$.

Namun, seiring semakin meningkat dan berkembangnya perbankan syariah, masih banyak masyarakat yang beranggapan bawah bank syariah tidak ada bedanya dengan bank-bank konvensional lainnya, hanya nama produk dan aspek d̦āhirīyahnya saja yang melabelkan ekonomi Islam. Padahal dalam prakteknya, perbankan syariah seperti bank muamalat yang sudah lebih dahulu mengembangkan perbankan syariah memberikan kontribusi terhadap pertumbuhan ekonomi Islam. Tentunya dengan berbagai kebijakan dan program yang memberikan konsepsi dasar berdasarkan prinsip-prinsip hukum Islam.

Hal ini menjadi tantangan bagi ekonomi Islam ke depan. Peningkatan dan peran bank syariah seharusnya menjadi tuntutan umat Islam dalam mengamalkan nilai-nilai ekonomi Islam dalam rangka meningkatkan kesejahteraan masyarakat Islam. Implementasi ekonomi Islam melalui perbankan syariah, bukan semata-mata hanya menggunakan pasar orang muslim saja. Tetapi diharapkan, perbankan syariah menjadi kebutuhan dan harapan terhadap masyarakat non-muslim dengan menggunakan sistem dan pola keseimbangan serta peningkatan kualitas pelayanan yang lebih baik. Sehingga bank syariah tidak dipersepsikan hanya bank milik orang Islam dan berorientasi kepada keuntungan material saja, namun lebih kepada substansi pola dan kinerja ekonomi Islam secara baik dan benar sesuai dengan tuntutan syariat Islam.

${ }^{4}$ Aji Dedi Mulawarman, "Masa Depan Ekonomi Islam: Dari Paradigma Menuju Metodologi" dalam Imanensi: Jurnal Ekonomi, Manajemen dan Akuntansi Islam, Volume 1 Nomor 1, (September 2013), h. 2. 


\section{PEMBANGUNAN EKONOMI ISLAM MELALUI PERBANKAN SYARIAH UMMAT}

Pesatnya pertumbuhan ekonomi melalui perbankan menjadi sebuah keharusan bagi masyarakat dalam melakukan dinamisasi keuangannya. Bertahannya ekonomi konvensional dengan berbagai sistem dan perspektif yang dianut, seperti sosialisme, kapitalisme dan berbagai prinsip perbankan dengan berbagai orientasinya.

Ekonomi Islam menawarkan sebuah perspektif yang berbeda melalui perbankan syariah. Secara prinsip, Su'aidi ${ }^{5}$ yang mengutip pemikiran M. Umer Chpra (lahir, 1933), merupakan salah seorang penggagas ekonomi Islam kontemporer, menyatakan bahwa ekonomi Islam merupakan cabang dari ilmu pengetahuan untuk kemaslahatan umat yang selaras dengan maqāṣid al-syariah. Dalam pandangannya, untuk mendukung terhadap kebijakan terhadap pembangunan ekonomi Islam dengan orientasi kesejahteraan masyarakat tanpa mengekang hak individu, maka diperlukan strategi dalam implementasinya, yaitu: (1) melaksanakan prinsip-prinsip Islam, yaitu rational economic man atau multiple ownership dan sosial justice;(2) intervensi negara; (3) restrukturisasi ekonomi; dan (4) keuangan publik (zakat pajak).

Setiap harta yang dimiliki oleh manusia, seyogyanya adalah milik Allah, manusia hanya dititipkan untuk kemanfaatan bagi sesame, dimana mencarinya, bagaimana cara mendapatkanya, dan untuk apa kegunaannya. Oleh karena itu, tuntutan agama dalam masalah ekonomi bagi mempunyai penekanan yang skunder, bukan primer. Pemenuhan terhadap kebutuhan masyarakat adalah tanggung jawab pemerintah dalam menjamin kesejahteraan masyarakatnya. Hal ini sesuai dengan UUD 1945 pasal 33 ayat (3) mengatakan bahwa bumi dan air dan kekayaan

${ }^{5}$ Mohammad Zaki Su'aidi, "Pemikiran M. Umer Chapra Tentang Masa Depan Ekonomi Islam” dalam Ishraqi, Volume 10, Nomor 1, (Juni 2012), h. 7. 
alam yang terkandung di dalamnya dikuasai oleh negara dan dipergunakan untuk sebesar-besarnya kemakmuran rakyat.

Keberadaan negara atas pemeliharaan terhadap kesejahteraan masyarakat harus lebih besar porsinya dalam kehidupan berbangsa dan bernegara. Secara prinsip, sebuah negara mempunyai orientasi yang paling substansial dalam penyelenggaraannya, yaitu kemaslahatan dan kesejahteraan bagi seluruh masyarakat. Seperti yang termaktub dalam UUD 1945, yang dinyatakan dalam alinea keempat, bahwa untuk membentuk suatu pemerintahan negara Indonesia yang melindungi segenap bangsa Indonesia dan seluruh tumpah darah Indonesia dan untuk memajukan kesejahteraan umum, mencerdaskan kehidupan bangsa, dan ikut melaksanakan ketertiban dunia yang berdasarkan kemerdekaan, perdamaian abadi dan keadilan sosial.

Intervensi negara penting dalam kerangka peningkatan kesejahteraan masyarakat. Negara sebagai satu kesatuan dalam kehiudpan berbangsa bagi seluruh rakyatnya, mempunyai peran penting dalam mengembangkan dan mengelola ekonomi bangsa. Tujuannya adalah tidak lain sebagai instrument untuk kepentingan seluruh rakyatnya, terutama dalam pemenuhan atas kebutuhan masyarakat dalam bidang ekonomi, yaitu tercapainya suatu kesejahteraan bagi seluruh rakyatnya.

Pengelolaan terhadap ekonomi negara merupakan bagian terpenting dalam meningkatkan kemaslahatan masyarakat. Restrukturisasi sebagai elaborasi dari pelaksanaan kebijakan terhadap ekonomi yang sudah dilakukan dengan evaluasi yang akan dilakukan. Kebijakan terhadap ekonomi bangsa membutuhkan sebuah proses yang komprehenshif dalam perkembangannya, karena secara parsial, menyesuaikan dengan kebutuhan pasar atau kebutuhan masyarakatnya. Dibutuhkan sebuah restrukturisi ekonomi untuk meningkatkan kesejahteraannya, bagi sumber daya manusia didalamnya, infrastruktur maupun sarana penunjang lainnya. Tentunya 
orientasi utamanya adalah untuk kesejahteraan masyarakat dan kemaslahatan bagi seluruh ummat manusia.

Alamsyah $^{6}$ berpendapat, bahwa perbankan syariah akan membawa kemaslahatan bagi ummat dan dapat meningkatkan kesejahteraan masyarakat secara umum. Indikatornya adalah: (1) underlying transaksi; (2) tidak ada sifat spekulatif; dan (3) sistem bagi hasil.

Underlying transaksi sebagai pendorong bagi perbankan syariah dalam memberikan pelayanan maksimal terhadap sektor riil, sehingga dampaknya dapat dirasakan secara langsung oleh mitra. Kedekatan perbankan syariah terhadap sektor rill karena faktor produknya. Pembiayaan dalam produk perbankan syariah dapat membantu peningkatan kesejahteraan masyarakat yang langsung beresntuhan dengan kondisi masyarakat. Lebih mudah dikenali, dipahami, dan dilakukan karena aspek kemanfaatan dan kegunaan bagi masyarakat.

Perbankan syariah tidak mempunyai produk yang bersifat spekulatif dalam transaksi ekonomi. Produk-produk spekulatif (gharar) mempunyai resiko tinggi terhadap kesinambungan ekonomi, terutama dalam pembiayaannya, jika tepat akan dapat, namun jika salah akan bermasalah. Hal ini dapat berdampak terhadap pertumbuhan lembaga perbankan. Spekulasi produk juga berdampak terhadap dinilai tidak mempunyai daya tahan dalam direct hit krisis keuangan global. Sehingga ancamannya akan terbendung dengan berbagai produk yang realistis.

Sistem bagi hasil dalam perbankan syariah menjadi menu utama dalam produk yang ditawarkan. Pofit-loss sharing sudah menjadi ruh bagi perbankan syariah yang memberikan dampak langsung terhadap kesejahteraan masyarakat. Pun demikian,

${ }^{6}$ Halim Alamsyah, "Perkembangan dan Prospek Perbankan Syari'ah Indonesia: Tantangan dalam Menyongsong MEA 2015", Makalah disampaikan pada Ceramah Ilmiah Ikatan Ahli Ekonomi Islam (IAEI), Milad ke-18 IAEI, (13 April 2012), h. 2. 
menjadi sistem bagi hasil juga menjadi safety bagi pemilik dana, dan deposan maupun bank itu sendiri secara adil, baik dan bijaksana. Sehingga pendanaan dapat dikelola secara professional dan aspiratif.

Hal itu tidak hanya dapat dilakukan melalui perkembangan dan peningkatan perbankan syariah, namun dapat dielaborasikan secara komprehensif tentang ekonomi syariah secara makro, yaitu melibatkan unsur ekonomi Islam melalaui berbagi konsep dan kebijakan strategisnya. Disamping itu, zakat merupakan bagian dari ekonomi Islam yang mempunyai peran strategis dalam melakukan upaya pengentasan terhadap kemiskinan di sebuah negara. Zakat sebagai panggilan bātinīyah dalam membentuk sebuah lembaga ekonomi syariah yang dibangun atas dasar dan prinsip keikhlasan untuk membantu sesama dalam meningkatkan kesejahteraan masyarakat.

Zakat merupakan kewajiban bagi seluruh ummat muslim yang termasuk di dalam rukun Islam yang keempat. Zakat wajib dikeluarkan bagi anak-anak maupun orang dewasa yang disesuaikan dengan kemampuannya. Secara epistemology, zakat sebagai pembersih atas rezeki atau harta yang dimilikinya dari berbagai kotoran bātinīyah. Zakat dikeluarkan atas perhitungan dari kekayaan yang dimilikinya. Secara aksiologi, zakat mempunyai peran penting di dalam meminimalisir kesenjangan terhadap sosial ekonomi masyarakat. Kaum du'afā, fakir miskin, miskin, maupun masyarakat yang mempunyai hak menerima zakat menjadi tumpuhan umat Islam dalam membantu meningkatkan kesejahteraan masyarakat.

Adapun zakat, mempunyai kemanfaatan dan kebergunaan dalam menopang dan membantu mengatasi permasalahan kemiskinan dan meningkatkan kesejahteraan masayarakat, antara lain: (1) menolong yang lemah dan susah agar dapat menunaikan kewajibannya atas Allah dan masyarakat; (2) mendidik diri sendiri untuk menunaikan perintah Allah atas apa 
yang diwajibkan kepadanya dengan mengajarkan kemuliaan, kedermawanan, dan menjadikan manusia yang pemurah dan penyayang. Disamping itu, dapat membersihkan diri dari sifatsifat tercela, kikir, sombong, angkuh, dan tamak sebagai sifat manusia; (3) menjadikan manusia lebih bersyukur atas nikmat Allah yang dianugerahkan kepadanya. Memberi lebih baik dari pada menerima. Sehingga filosofi atas zakat menjadi panutan dan tuntutan dalam kehidupannya, bahwa harta yang dimilikinya, hanyalah titipan dari Allah; (4) memberikan sumbangsih terhadap perbuatan buruk yang mungkin dapat ditimbulkan oleh orang yang kurang mampu dalam perekonomiannya, sehingga berbuat kurang baik hanya untuk bertahan hidup dan memenuhi kebutuhannya, termasuk mendapatkan dengan menghalakan segala cara; dan (5) zakat sebagai penyeimbangan dari ketimpangan-ketimpangan ekonomi di dalam kehidupan masyarakat. Tidak dapat dipungkiri, bahwa strata masyarakat sosial masih melihat dari aspek ekonominya. Jarak antara masyarakat yang kaya dengan yang miskin masih menjadi tantangan negara dalam pembangunannya. Zakat mempunyai fungsi penyeimbang antar yang mempunyai strata ekonomi kelas atas dan kelas bawah menjadi setara. Kesetaraan dalam bermasyarakat mempunyai peran penting untuk mendorong dan meningkatkan kualitas hidup masyarakat yang lebih baik dan sejahtera ${ }^{7}$.

Pengelolaan terhadap zakat harus dilakukan secara professional dan proporsional dalam implementasinya, tentunya didukung oleh sarana dan prasana serta sumber daya manusia yang kompeten. Zakat mempunyai korelasi seimbang dan peran penting terhadap pemenuhan akan masyarakat kurang mampu, jika dikelola dengan baik. Pengelolaan zakat sebagai keungan publik harus dilakukan secara professional pula, baik pada penerimaannya, maupun prinsip pengeluarannya, sehingga

${ }^{7}$ Sulaiman Rasjid, Fiqih Islam, (Cet. ke-57; Bandung: Sinar Baru Algensindo, 2012), h. 217-218. 
keseimbangan dan pengeluaran atas zakat dapat diaplikasikan kepada orang yang berhak menerimanya. Sehingga dapat membantu menciptakan kemandirian secara ekonomi maupun sosial. Kemandirian ekonomi, tentunya harus didukung oleh pengembangan dan pendidikan serta pelatihan yang disesuaikan dengan kemampuan, keberadaan, maupun aspek kebutuhan.

Penjelasan keempat strategi di atas menggambarkan sebuah ekonomi Islam yang käffah dan menyeluruh. Perspektif awal dalam pembangunan ekonomi dilakukan melalui pandangan dan paradigma yang dibangun atas individu maupun masyarakat secara luas. Pandangan terhadap keberadaan ekonomi sebagai syarat penting dalam pembangunannya. Harta dan kekayaan adalah millik Allah, sementara manusia hanya dititipkan sebagai amanah. Tujuannya adalah tentu untuk kebaikan dan kebijakan, baik dalam konsep penerimaan maupun pengeluarannya. Penekanan terhadap pemahaman ini, menjadi salah satu faktor untuk menentukan arah kebijakan ekonomi Islam selanjutnya. Kebaikan dan keberkahan dalam pengelolaan ekonomi menjadi pilihan utamanya, dengan orientasi kemaslahatan bagi masyarakat.

Keberadaan negara sebagai tempat adanya sebuah sumber daya alam, menjadi tanggung jawab dan kuasanya di dalam pengelolaan dan implikasinya secara menyeluruh terhadap masyarakatnya. Intervensi negara atas ekonomi secara umum menjadi sebuah kewajiban dan diatur dalam peraturan perundang-undangan. Begitupula terkait dengan pengelolaan dan pengembangan ekonomi harus terukur sesuai dengan proporsi dan komposisinya, yaitu dengan restrukturisasi dan reformasi terhadap sistem ekonomi, konsep dan pelaksanaan, serta menjadi formulasi untuk pengembangan ekonomi kerakyatan kedepan menjadi lebih baik dan berkualitas, dengan indikator utamanya adalah kesejahteraan dan kemaslahatan masyarakatnya. 
PERAN PERBANKAN SYARIAH: TINJAUAN TEORITIS DAN PRAKTIS

Secara teoritis, sistem perbankan syariah dalam aspek penawaran mempunyai peran dan fungsi yang sama dengan bank konvensional, yaitu adanya harga barang itu sendiri, biaya produksi, harga barang lainnya, dan teknologi sebagai faktor dalam penawaran produk. Namun dalam perbankan syariah menggunakan konsep muḍārabah dan musyārakah (nisbah bagi hasil) ${ }^{8}$.

Tabel 1

Kinerja Keuangan Bank Umum Syariah dan Bank Umum Konvensional

\begin{tabular}{|c|c|c|c|c|c|c|c|c|c|c|}
\hline \multirow{2}{*}{$\begin{array}{c}\text { Rasion } \\
\text { (\%) }\end{array}$} & \multicolumn{5}{|c|}{ Bank Umum Syariah } & \multicolumn{5}{|c|}{ Bank Umum Konvensional } \\
\hline & 2006 & 2007 & 2008 & 2009 & 2010 & 2006 & 2007 & 2008 & 2009 & 2010 \\
\hline CAR & 13,73 & 10,67 & 12,81 & 10,77 & 16,7 & 21,27 & 19,30 & 16,76 & 17,42 & 17,18 \\
\hline LDR & 98,90 & 99,76 & 103,65 & 89,70 & 87,60 & 61,56 & 66,32 & 74,58 & 72,88 & 75,21 \\
\hline NPL & 4,75 & 4,05 & 4,17 & 4,01 & 6,50 & 6,07 & 4,07 & 3,20 & 3,31 & 2,56 \\
\hline BOPO & 76,77 & 76,54 & 81,75 & 84,39 & 82,38 & 86,98 & 84,05 & 88,59 & 86,63 & 86,14 \\
\hline ROA & 1,55 & 2,07 & 1,42 & 1,48 & 1,58 & 2,64 & 2,78 & 2,33 & 2,60 & 2,86 \\
\hline
\end{tabular}

Sumber: Statistik Perbankan Syariah (2010) dan Statistik Perbankan Konvensional (2011), dalam Widya Wahyu Ningsih ${ }^{9}$ (2012).

${ }^{8}$ Desti Anggraini, "Faktor-Faktor yang Mempengaruhi Penawaran Pembiayaan Mud̄ārabah dan Musyārakah: Studi Kasus Bank Syari'ah Mandiri”, Tesis tidak diterbitkan, (Jakarta: Program Studi Kajian Timur Tengah dan Islam Program Pascasarjana Universitas Indonesia, 2005), h. 16.

${ }^{9}$ Widya Wahyu Ningsih, "Analisis perbandingan Kinerja Keuangan Bank Umum Syari'ah dengan Bank Umum Konvensional di Indoneisa", Skripsi tidak diterbitkan, (Makassar: Jurusan Manajemen Fakultas Ekonomi dan Bisnis Universitas Hasanuddin, 2013), h. 18. 
Praktis, perbankan syariah mempunyai peran dan fungsi yang sama dengan bank konvensional. Sistem dan teknik pengelolaannya yang berbeda. Pada table di atas dijelaskan bahwa COR bank syariah mengalami rating yang dinamis sejak tahun 2006 sampai tahun 2010 mengalami peningkatan, antara 13\% pada tahun 2006 dan $16 \%$ pada tahun 2010. Tidak berbeda dengan bank konvensional yang mengalami dinamisasi pertumbuhannya yaitu $21 \%$ pada tahun 2006 dan pada tahun 2010 adalah $17 \%$.

Peran bank syariah saat ini mengalami geliat yang sangat tinggi. Hal ini dipengaruhi oleh kebutuhan masyarakat akan perbankan, terutama bagi masyarakat muslim dengan menggunakan sistem syariah sesuai dengan ketentuan hukum Islam. Meningkatnya permintaan nasabah atas keberadaan bank syariah juga dipengaruhi oleh konsep yang ditawarkan oleh perbankan syariah dalam pengelolaan dan manajemen keuangan secara Islami. Pun demikian, prinsip yang digunakan juga mempunyai peran strategis dalam meningkatkan kualitas kepada pelanggan.

Perkembangan perbankan syariah mempunyai filterisasi bagi nasabah dalam melakukan investasi dengan berbagai program yang ditawarkan sesuai dengan tuntutan agama. Sehingga dapat menarik simpati masyarakat dalam pengelolaannya yang memang mendapatkan pengawasan dari para pemangku kebijakan perbankan secara syariah. Sehingga filterisasi dapat berjalan secara obyektif, efektif, dan efisien.

Namun jika di telaah lebih mendalam, menurut Mulawarman, ${ }^{10}$ bahwa fokus perbankan syariah masih pada aspek areal retail, jasa, perdagangan, hingga akhir tahun 2012. Jumlah pembiayaan bidang UKM cenderung mengalami kenaikan dari tahun ke tahun, pada tahun 2006 tumbuh 14, 872 triliyun (72,7\%) menjadi 80,456 $(69,9 \%)$ triliyun pada tahun 2012. Namun pada pertumbuhannya mengalami penurunan, yaitu pada tahun 2006

${ }^{10}$ Ibid; Mulawarman, “Masa Depan Ekonomi Islam...”, h. 2-3. 
72,74 triliyun, menurun pada tahun 2012 61,72 triliyun. Sehingga pada total pertumbuhan tahun 2006, dari 20,4 triliyun menjadi 130 triliyun. Hal ini juga dipengaruhi oleh pertumbuhan signifikan dari usaha besar yang terus tumbuh pada tahu 2006 yang hanya 5,6 triliyun, menjadi 50 triliyun pada tahun 2012.

Tabel 2

Pembiayaan Bank Umum Syariah dan UUS berdasarkan Golongan Pembiayaan

\begin{tabular}{lcccc}
\hline Pembiayaan & \multicolumn{2}{c}{2006} & \multicolumn{3}{c}{ September 2012 } \\
\hline UKM & $14,872 \mathrm{~T}$ & $72,74 \mathrm{~T}$ & $80,456 \mathrm{~T}$ & $61,72 \mathrm{~T}$ \\
\hline Usaha Besar & $5,573 \mathrm{~T}$ & $27,26 \mathrm{~T}$ & $49,902 \mathrm{~T}$ & $38,28 \mathrm{~T}$ \\
\hline Total & $20,445 \mathrm{~T}$ & $100 \%$ & $130,358 \mathrm{~T}$ & $100 \%$ \\
\hline
\end{tabular}

Sumber: Statistik Perbankan Syariah September 2012 (diolah), dalam Aji Dedi Mulawarman (2013:3).

Sementara itu, data yang diolah oleh Statistik Perbankan Syariah (2012), dalam Mulawarman ${ }^{11}$, menjelakan bahwa komposisi pembiayaan bank syariah terhadap akad mudāarabahnya mengalami peningkatan signifikansi, tahun 2006 sebesar 4,062 trliyun menjadi 6,597 triliyun. Pada tahun 2011 semakin naik menjadi 10,229 triliun, dan ditutup dengan angka 11,359 triliun pada September 2012. Begitu juga pada akad Musyārakahnya terus mengalami peningkatan, dari tahun 2006 sebesar 2,335 triliyun naik 24,481 triliun pada September tahun 2012. Sementara pada akad murabahanya tahun 2006 sebesar 12,624, tahun 2009 adalah 26,321 triliun. Pada tahun 2011 mengalami peningkatan, yaitu sebesar 56,365 triliun dan ditutup pada September 2012 sebesar 77,153 triliyun.

Data di atas menunjukkan bahwa peran perbankan syariah mempunyai andil dan peran penting dalam pengembangan

\footnotetext{
${ }^{11}$ Mulawarman, Ibid., h. 4.
} 
ekonomi secara nasional. Peningkatan pembiayaan perbankan syariah melalui resapan bagi UKM dan Usaha besar terus bergeliat. Begitu juga dengan aspek komposisi sistem dalam perbankan syariah mengalami rating yang sangat bagus dari tahun ke tahun. Sehingga total pada tahun 2012 dalam komposisi pembiayaan akad dalam sistem perbankan syariah mengalami kenaikan yang cukup bagus, yaitu 130,357 triliun, dari 20,444 triliyun pada tahun 2006.

Tabel 3

Urutan Negara Berdasarkan Aset Syariah

\begin{tabular}{|c|c|c|c|c|c|}
\hline Rank & Country & $\begin{array}{l}\text { Shariah- } \\
\text { Compliant } \\
\text { Assets Sm }\end{array}$ & Rank & Country & $\begin{array}{l}\text { Shari'ah- } \\
\text { Compliant } \\
\text { Assets Sm }\end{array}$ \\
\hline$T$ & Iran & 293.165 .8 & 1 & Iran & 314.897 .4 \\
\hline 2 & Saudi Arabia & 127.896 .1 & 2 & Saudi Arabia & 138.238 .5 \\
\hline 3 & Malaysia & $86,288.2$ & 3 & Malaysia & $102,639.4$ \\
\hline 4 & UAE & $84,036.5$ & 4 & UAE & 85.622 .6 \\
\hline 5 & Kuwait & 67.630 .2 & 5 & Kuwait & 69.088 .8 \\
\hline 6 & Bahrain & $46,159.4$ & 6 & Bahrain & 44.858 .3 \\
\hline 7 & Qatar & 27.515 .4 & 7 & Qacar & 34.676 .0 \\
\hline 8 & UK & 19.410 .5 & 8 & Turkey & 22.561 .3 \\
\hline 9 & Turkey & 17.827 .5 & 9 & UK & 18.949 .0 \\
\hline 10 & Bangladosh & 7453.3 & 10 & Bangladesh & 9.365 .5 \\
\hline it & Sudan & 751.1 & II & Sudan & 9.259 .8 \\
\hline 12 & Egypt & 6299.7 & 12 & Egypt & 7.227 .7 \\
\hline 13 & Pakistan & 5126.1 & 13 & Indonesia & 7.2222 \\
\hline 14 & fordan & 4621.6 & 14 & Pakistan & 6.203 .1 \\
\hline 15 & Syria & 3838.8 & 15 & Syria & 5.527 .7 \\
\hline 16 & Iraq & 3815 & 16 & Jordan & 5,0424 \\
\hline 17 & Indonesia & 3388.2 & 17 & Brunei & 3.314 .7 \\
\hline 18 & Brunei & 3201.4 & 18 & Yemen & $2,338.7$ \\
\hline 19 & Yernen & 1318.3 & 19 & Thailand & 1.360 .8 \\
\hline 20 & Switzertand & 1040.6 & 20 & A/geria & 1.051 .1 \\
\hline 21 & Mauritius & 943.5 & 21 & Mauritius & 9922 \\
\hline 22 & Ageria & 837.5 & 22 & Switzerland & 935.5 \\
\hline 23 & Tunisia & 632.3 & 23 & Tunisia & 770.1 \\
\hline 24 & Singapore & 618 & 24 & Singapore & 725.0 \\
\hline 25 & Thailand & 495.5 & 25 & Palestine & 612.5 \\
\hline
\end{tabular}

Sumber: Maris Strategies \& the Banker (2010), dalam Alamsyah (2012:2).

Peran penting perbankan syariah dalam pertumbuhan ekonomi di Indonesia, juga disampaikan oleh Halim Alamsyah, ${ }^{12}$

${ }^{12}$ Ibid. Alamsyah, "Perkembangan dan Prospek Perbankan...", h. 2. 
bahwa meningkatnya peran perbankan syariah dapat dilihat dari meningkatnya ranking total asset keuangan syariah mencapai US $\$ 7,2$ miliyar pada tahun 2010, yaitu urutan ke-13, dari peringkat ke-17 pada tahun 2009. Sementara itu, pada tahun 2011, perkembangan perbankan syariah terus mengalami kenaikan dengan asumsi total asset melebihi US\$20 miliyar.

\section{STRATEGI PERBANKAN SYARIAH DALAM MENGHADAPI MASYARAKAT EKONOMI ASEAN 2015}

Peran perbankan syariah dalam konteks modernisasi saat ini, terutama dalam konsep negara Indonesia tidak hanya berfokus kepada nasabah muslim. Masyarakat Indonesia yang multikultural dengan berbagai macam ragam budaya, bahasa, dan agama menjadi market yang sangat penting dalam pengembangan perbankan syariah. Nasabah, dalam hal perbankan sejatinya melihat kepada aspek pelayanan, program, maupun jaminan keamanan. Sehingga peningkatan perkembangan bank syariah terus berkesinambungan sesuai dengan kebutuhan masyarakat.

Menghadapi MEA (Masyarakat Ekonomi Asean) tahun 2015, kesiapan bank syariah harus terus mengikuti perkembangan global dalam bidang peningkatan kualitas layanan, program yang representative dan qualified, dan menjamin atas simpanan nasabah secara professional dan akuntabel. Disamping itu, strategi pengelolaan dan manajemen dalam pengelolaan perbankan harus terus di updating, berkaitan dengan arus ekonomi global yang semakin ekstrimisme dalam kompetisi pasar, sehingga pengelolaan perbankan syariah dapat terjamin dengan gelombang ekonomi yang semakin besar dan tantangan yang semakin sulit.

Untuk memenuhi kebutuhan pasar dan keinginan masyarakat dalam perbankan, maka Biro Perbankan Syariah Bank Indonesia (2002), melalui cetak biru pengembangan perbankan syariah di Indonesia dengan sasaran sampai tahun 2011 mencatat, 
bahwa upaya yang dilakukan adalah sebagai berikut: (1) terpenuhinya prinsip syariah dalam operasional perbankan; (2) ditetapkannya prinsip kehati-hatian dalam operasional perbankan syariah; (3) terciptanya sistem perbankan syariah yang kompetitif dan efisien; dan (4) terciptanya stabilitas sistemik serta terealisasinya kemanfaatan bagi masyarakat luas ${ }^{13}$.

Secara konsepsi, maka strategi di atas harus diimbangi oleh prinsip-prinsip ekonomi Islam. Prinsip-prinsip dasar ekonomi Islam menurut M. Umer Chapra (2001), antara lain: (1) prinsip tauhid; (2) prinsip khilafah; dan (3) prinsip keadilan ${ }^{14}$.

Prinsip tauhid sebagai prinsip utama dalam ekonomi Islam, yaitu menekankan kepada aspek akidah dan keimanan. Prinsip ini menjadi pondasi bagi setiap manusia dalam berinteraksi maupun bertransaksi. Harus diyakini bahwa setiap apa yang dimiliki adalah hanya sebuah titipan dari Allah swt. dan merupakan amanah yang harus dipertanggungjawabkan kelak, dari mana mendapatkannya dan untuk apa penggunaannya. Sehingga ekonomi Islam tidak hanya dimaknai sebagai asas keuntungan, tapi harus ditekankan kepada asas keyakinan untuk saling membantu satu sama lain sebagai penyeimbang bagi kemaslahatan dan kesejahteraan masyarakat.

Sedangkan prinsip kedua adalah prinsip khilafah. Manusia diciptakan oleh Allah adalah untuk menjadi pemimpin atau khalifah di bumi. Khalifah tidak hanya memimpin saja, namun lebih kepada menformulasikan, mengimplementasikan dan controlling terhadap apa yang sudah dilakukan. Prinsip khilafah dalam ekonomi Islam adalah bermakna, bahwa setiap manusia

${ }^{13}$ Ali Mutasowifi, "Menggagas Strategi Pengembangan Perbankan Syari'ah di Pasar Nonmuslim" dalam Jurnal Universitas Paramadina, Volume 3, Nomor 1, (September 2003), h. 26

${ }^{14}$ Lely Shofa Imama', “Ekonomi Islam: Rasional dan Relevan”, Resensi Buku "Menjawab Keraguan Berekonomi Syari'ah", TIM Penulils MSI UII yang Diterbitkan oleh MSI UII dan Safiria Press, 2008, La_Riba, Jurnal Ekonomi Islam, Volume II, Nomor 2, (Desember 2008), h. 312-313. 
mempunyai kewajiban untuk mengelola dan memanjemen semua ciptaan Allah yang diamanahkan kepada setiap orang. Tujuannya tentu untuk kemaslahatan dan kesejahteran bagi dirinya dan masyarakat, serta untuk melindungi dan mengembangkan setiap karuni yang Allah berikan sebagai aspek kemanfaatan. Artinya bahwa, setiap yang Allah anugerahkan adalah untuk kemanfaatan dirinya, dan harus dilakukan sebagai istikhārah serta harus didapatkan secara halālan toyyiban.

Prinsip yang terakhir adalah prinsip keadilan. Keadilan sebagai prinsip dalam ekonomi Islam adalah suatu keniscayaan. Sesungguhnya setiap manusia mempunyai keinginan untuk mendapatkan rejeki sebanyak-banyaknya dan diusahakan untuk bisa berkembang sebesar-besarnya. Namun ekonomi Islam, memberikan pertimbangan mendasar terhadap praktek-praktek pemenuhan kebutuhan dasar manusia, distribusi kelayakan akan kebutuhannya, serta pemenuhan terhadap pemerataan dalam kehidupan yang layak. Prinsip ekonomi dalam Islam memberikan pandangan komprehensif terhadap kehidupan manusia, yaitu berlaku adil terhadap pemenuhan akan kebutuhan hidupnya. Artinya bahwa berlaku adil terhadap sumber-sumber rejeki yang didapatkan, aspek penggunaan yang sesuai dengan kebutuhan dan kelayakan, serta menggunakan prinsip stabilitas dan pertumbuhan sebagai icon dalam distribusinya.

Semakin dekatnya pelaksanaan MEA, memberikan artikulasi bagi perbankan syariah dalam menjadikan tantangan sebagai prospek pasar ekonomi Islam dalam kancah global. Perbankan syariah saat ini sedang dalam gejolak untuk berkembang dan meningkat. Nasabahnyapun sudah tidak melihat kepada ideology, namun lebih mengandalkan aspek layanan dan program, sehingga masyarakatpun lebih memilih pelayanan yang baik dan program yang professional dalam perbankan. Hal ini menjadi tantangan bagi perbankan syariah. 
Tantangan perbankan syariah dalam jangka pendek adalah sebagai berikut: (1) pemenuhan gap sumber daya insani; (2) inovasi pengembangan produk dan layanan perbankan yang kompetitif serta berbasis atas kebutuhan masyarakat; dan (3) keberlangsungan sosialisasi dan edukasi. Sementara jangka panjangnya, antara lain: (1) dibutuhkannya kerangka hukum yang dapat dijadikan sandaran dalam penyelesaian masalah keuangan syariah secara komprehenshf; (2) adanya kodifikasi produk dan standar regulasi secara nasional dan global sebagai jembatan dalam perbedaan terhadap fiqh muāmmalah; dan (3) diperlukannya nilai imbal hasil (rute of return) bagi keuangan syariah $^{15}$.

Tantangan-tangan di atas menjadi tugas perbankan syariah dalam mengembangkan operasional program maupun pelayanan serta sumber daya manusia yang ada. Baik tantangan jangka pendek maupun tantangan jangka panjang mempunyai kerangka kebijakan strategis. Terutama dalam menghadapi pasar global yang sudah tinggal menghitung bulan, yaitu pada MEA 2015. Sehingga dalam aplikasinya, di dalam pengembangan perbankan syariah sudah ada antisipasi terhadap kelemahan-kelemahan yang muncul serta mempunyai solusi strategsi terhadap permasalahan yang akan dihadapi nantinya. Hal ini seperti dijelaskan pada tantangan jangka pendek yang sudah mengatur tentang bagaimana menjadikan sumber daya manusia sebagai sumber daya insani, yang dapat menjalankan dan mempunyai kinerja yang kompetitif dan komprehensif terhadap pemberian layanan perbankan secara professional.

\section{PENUTUP}

Peran perbankan syariah dalam pembangunan ekonomi Islam memberikan implikasi yang signifikan terhadap kesejahteraan masyarakat. Ekonomi Islam yang di representasikan melalui bank syariah dapat memberikan solusi

${ }^{15}$ Imama', Ibid. Alamsyah, “Perkembangan dan Prospek...”, h. 4-5. 
alternatif bagi masyarakat dalam mengatur dan memanjamen masalah keuangannya. Pun demikian, dalam persaingan global, perbankan syariah sudah mulai menunjukkan ritme keuangan syariah yang kompetitif. Sehingga keberadaan perbankan syariah dalam menghadapi MEA 2015 sudah mempunyai strategi dan planning yang siap dijalankan, yaitu melalui berbagai tantangan dan konsepsi yang harus dilakukan dalam jangka pendek maupun jangka panjang.

Secara teoritis, perbankan syariah mempunyai gelombang magnet yang sangat tinggi terhadap dunia akademis maupun research. Perbankan syariah terus mengalami peningakatan dalam kajian, penelitian, perbandingan secara teoritik serta pembelajaran dengan berbagai isu perbankan. Sehingga perbankan syariah mempunyai peran penting dalam ilmu pengetahuan, terutama dalam hal ekonomi Islam.

Perbankan syariah dalam konteks aplikasi atau prakteknya, juga mengalami peningkatan yang signifikan dalam kondisi kesiapan pasar global. Menghadapi MEA 2015, perbankan syariah sudah menyiapkan diri dengan berbagai program handalan dan kebijakan-kebijakan strategis dalam memberikan kenyamanan, keamanan, keleluasaan dan kebaikan bagi nasabahnya. Pun demikian, pelayanan yang prima dan berkualitas terus dilakukan dan ditingkatkan melalui peningkatan kompetensi bagi sumber daya manusia di dalamnya. Begitu juga dengan pengelolaan dan manajemen perbankan perlu dilakukan secara komprehensif. Sehingga internalisasi pengelolaan dapat dijadikan sebagai sumber dalam pengembangan ekternalisasi perbankan melalui penyatuan program yang mempunyai akuntabilitas dan professional.

\section{DAFTAR PUSTAKA}

Abdul GhofurAnshori, "Sejarah Perkembangan Hukum Perbankan Syariah di Indonesia dan Implikasinya bagi Praktek 
Perbankan Syariah" dalam La_Riba, Jurnal Ekonomi Islam, Volume II, Nomor 2, (Desember 2008), h. 159-172.

Aji Dedi Mulawarman, "Masa Depan Ekonomi Islam: Dari Paradigma Menuju Metodologi". Imanensi,Jurnal Ekonomi, Manajemen dan Akuntansi Islam, Volume 1, Nomor 1, (September 2013), h. 1-13.

Ali Mutasowifi, "Menggagas Strategi Pengembangan Perbankan Syariah di Pasar Nonmuslim", Jurnal Universitas Paramadina, Volume 3, Nomor 1, (September 2003), h. 25-39.

Desti Anggraini, "Faktor-Faktor yang Mempengaruhi Penawaran Pembiayaan Mudharabah dan Musyarakah: Studi Kasus Bank Syariah Mandiri”, Tesis tidak diterbitkan, Jakarta: Program Studi Kajian Timur Tengah dan Islam, Program Pascasarjana Universitas Indonesia, 2005.

Halim Alamsyah, "Perkembangan dan Prospek Perbankan Syariah Indonesia: Tantangan dalam Menyongsong MEA 2015", Makalah disampaikan pada Ceramah Ilmiah Ikatan Ahli Ekonomi Islam (IAEI), Milad ke-18 IAEI, (13 April 2012).

Lely Shofa Imama', "Ekonomi Islam: Rasional dan Relevan”. Resensi Buku "Menjawab Keraguan Berekonomi Syariah". TIM Penulils MSI UII. Diterbitkan oleh MSI UII dan Safiria Press. 2008, dalam La_Riba, Jurnal Ekonomi Islam, Volume II, Nomor 2, (Desember 2008), h. 309-317.

Mohammad Zaki Su'aidi, "Pemikiran M. Umer Chapra Tentang Masa Depan Ekonomi Islam" dalam Ishraqi, Volume 10, Nomor 1, (Juni 2012), h. 1-13.

Sulaiman Rasjid, Fiqih Islam, Cet. ke-57; Bandung: Sinar Baru Algensindo, 2012.

Taufiqul Hulan,"Jaminan Dalam Transaksi Akad Mudharabah Pada Perbankan Syariah" dalam Jurnal Mimbar Hukum, Volume 22, Nomor 3, (Oktober 2010), h. 520-533. 
Vol. 11, No. 2, Desember 2014: 293-314

Widya Wahyu Ningsih, “Analisis perbandingan Kinerja Keuangan Bank Umum Syariah dengan Bank Umum Konvensional di Indoneisa", Skripsi tidak diterbitkan, Makassar: Jurusan Manajemen Fakultas Ekonomi dan Bisnis Universitas Hasanuddin, 2012. 